\title{
Dying for a Cause: Meaning, Commitment, and Self-Sacrifice
}

Antti Kauppinen

Forthcoming in Royal Institute of Philosophy Supplement, ed. Michael Hauskeller.

Choose to die well while you can; wait too long, and it might become impossible to do so. - Gaius Musonius Rufus

All men must die, but death can vary in its significance. - Mao Zedong

On the 18th of February 1943, members of the anti-Nazi resistance group White Rose distributed copies of their sixth leaflet at the University of Munich. Before they left, one of them, Sophie Scholl, flung the remaining copies into the atrium from the top floor. She was seen and taken into Gestapo custody with her brother Hans. Being a young woman, Sophie was given the option to recant and save herself, but she refused. In court, she explained their actions as follows:

Somebody, after all, must make a start. What we said and wrote is also believed by so many others. They just don't dare to say it out loud. ${ }^{1}$

Predictably, the Scholls were sentenced to death for treason and executed. While in prison, Sophie discussed her coming execution with a cellmate, Else Gebel, who reported her saying the following:

\footnotetext{
${ }^{1}$ See http://www.mythoselser.de/texts/scholl-urteil.htm for the original German.
} 
What does my death matter, if through our actions thousands of people will be shaken and awakened? ... I could also die of illness, but would it have the same meaning? ${ }^{2}$

Well, probably not. Dying for a cause can be more meaningful than dying from an illness, including in the sense of giving meaning to one's life. What I want to explore in this paper is exactly what this means and why and when it is the case. For much of it, I will be mapping out the conceptual space rather than giving arguments, since I don't think philosophers have written much directly on the topic, though of course Stoics and others have addressed issues in the ballpark, as the quotes from Rufus and Mao suggest.

I will proceed as follows. First, I will distinguish between three varieties of meaning in life, drawing in part on psychological research on experiences of meaning. Next, I will define what I mean by a 'cause', and distinguish between the different ways one can be said to die for a cause. I also consider examples of both successful and failed cases of promoting a cause by risking or facing death. Third, I draw on the previous sections to set out conditions for when dying for a cause contributes to the different varieties of meaning in life. In the final section, I turn to the question of how dying for a cause can amount to self-sacrifice even when it makes one life more meaningful and is therefore, on my view, in an important way in one's self-interest in the right circumstances.

\footnotetext{
${ }^{2}$ From Else Gebel's letter to Sophie Scholl's parents, online in the original German at http://www.mythoselser.de/texts/scholl-gebel.htm.
} 


\section{Three Meanings of Meaning in Life}

I am going to start by clarifying what it means to say that someone's life is meaningful or is made meaningful by something. I am going to argue that there are at least three different philosophically interesting things this could amount to. ${ }^{3}$

My argument begins with the assumption that someone's life is meaningful if and only if it is fitting to experience it as meaningful. ${ }^{4}$ The reason this connection matters is that if there are many distinct experiences of meaning, it follows that there are many different ways for life to be meaningful. And indeed, in recent work in psychology, it has become common to think that there are indeed a number of distinct experiences of meaning. To be sure, quite often psychologists speak as if there are just three different aspects of meaning, as Login George and Crystal Park do in the following:

We define MIL [meaning in life] as the extent to which one's life is experienced as making sense, as being directed and motivated by valued goals, and as mattering in the world. ${ }^{5}$

But as Frank Martela and Michael Steger rightly emphasize, these experiences of intelligibility, purpose, and mattering can and do come apart and have different practical roles. ${ }^{6}$ Let's start with intelligibility. I have recently argued that psychologists tend to exaggerate the role of intelligibility in experiences of meaning, especially when it comes to merely perceiving patterns of some sort rather than randomness. ${ }^{7}$ But there is something to

\footnotetext{
${ }^{3}$ For more details, see Antti Kauppinen, 'The Experience of Meaning', in Iddo Landau (ed.), The Oxford Handbook of Meaning in Life (Oxford: Oxford University Press, forthcoming).

${ }^{4}$ For a defense of this assumption, see Antti Kauppinen, 'Meaningfulness and Time', Philosophy and Phenomenological Research 84 (2012), 345-377, at 352-355.

${ }^{5}$ Login George and Crystal Park, 'Meaning in Life as Comprehension, Purpose, and Mattering: Toward Integration and New Research Questions', Review of General Psychology 20 (2016), 205-220, at 206.

${ }^{6}$ Frank Martela and Michael Steger, 'The Three Meanings of Meaning in Life: Distinguishing Coherence, Purpose, and Significance', Journal of Positive Psychology 11 (2016), 531-545.

${ }^{7}$ In Kauppinen, 'Experience of Meaning'.
} 
the thought that for our own lives to make sense to us, we must see in their twists and turns some recognizable variation of culturally available models (see especially the work of Helena de $\mathrm{Bres}^{8}$ ). What I emphasize is that for us to find our lives intelligible in the sense that is linked to having a reason to live and not merely as something that fits into an explanatory framework, we must also regard the choices we've made as having been aimed at something sufficiently good that offers a kind of narrative justification for them. ${ }^{9}$ This sort of intelligibility can be called into question in cases of subjectively irrational life choices, personal loss, or radical cultural change, which may result in disorientation - I don’t know who I am or where I am going any more.

Even if you do find your life intelligible in this way, you may experience it as meaningless in the sense of lacking purpose. As I use the term, experiencing our lives as purposeful is a matter of having some orienting aim which we take to provide reasons for action and which we believe our actions to serve. Sense of purpose is thus manifest in enthusiastic motivation, and missing in boredom or depression. While it normally goes together with intelligibility, there is such a thing as newfound purpose that you can have even while experiencing your life as a whole as not making sense.

Finally, for us to experience our lives as meaningful in the sense of mattering is for us to find that actions that express our authentic selves successfully serve some objective or intersubjective value - that we purposefully make a positive difference to something or someone important to us when it is challenging to do so. (Note that our lives can be important without mattering in this sense. ${ }^{10}$ ) I think this kind of experience consists primarily in

\footnotetext{
${ }^{8}$ Helena de Bres, 'Narrative and Meaning in Life', Journal of Moral Philosophy 15 (2016), 545-571.

${ }^{9}$ See Alasdair MacIntyre, After Virtue: A Study in Moral Theory (Notre Dame, IN: University of Notre Dame Press, 1981) for a classic account of this kind of view.

${ }^{10}$ For importance, see Guy Kahane, 'Importance, Value, and Causal Impact', Journal of Moral Philosophy (forthcoming). Briefly, the two key differences between importance and mattering are that a life or an action can be important without mattering in virtue of making a large negative difference to intrinsic value (Stalin's actions were important), and in virtue of accidentally making a large positive difference to intrinsic value (if, unbeknownst to me, my breathing out happened to produce chemicals that would stabilize the world's $\mathrm{CO}_{2}$ levels, my life would be important!).
} 
feelings of fulfilment, agential pride, self-esteem, and confident hope, which affectively construe our past or on-going actions in such manner. Evidently, we can find our lives intelligible or purposeful without experiencing such feelings. Experiences of meaninglessness in this respect consist in feelings of failure or angst, which I take to be an existential feeling involving the thought that nothing is ultimately worthwhile. ${ }^{11}$

While these experiences are distinct, I do think that there is what I call a negative rational dependence among them. What I mean by this is that while you can have a sense of comprehension without a sense of purpose, if you experience your life as lacking purpose, it is not rational for you to experience it as (fully) intelligible either, because leading up to something worth pursuing is an important part of the experience of intelligibility. Similarly, if you think that your life doesn't and won't matter, it is not rational to experience a sense of purpose, because it entails thinking that you won't realize an objectively or intersubjectively valuable aim. In this sense, experiences of mattering seem to me to be the most fundamental experiences of meaning - existential anxiety rationally, and typically, undercuts sense of purpose and the intelligibility of one's life as a whole.

The table below (modified from Kauppinen forthcoming) summarizes the discussion so far:

\begin{tabular}{|l|l|l|l|}
\hline Dimension & $\begin{array}{l}\text { Sense-making: } \\
\text { contribution to a } \\
\text { desirable pattern }\end{array}$ & $\begin{array}{l}\text { Purpose and } \\
\text { resonance: } \\
\text { Experience } \\
\text { type }\end{array}$ & $\begin{array}{l}\text { Mattibution to } \\
\text { contribution to } \\
\text { value beyond } \\
\text { the self }\end{array}$ \\
\hline $\begin{array}{l}\text { Experience of } \\
\text { meaning }\end{array}$ & $\begin{array}{l}\text { Sense of } \\
\text { comprehension } \\
\text { and narrative } \\
\text { justification }\end{array}$ & $\begin{array}{l}\text { Enthusiastic } \\
\text { future- or } \\
\text { present-oriented } \\
\text { motivation }\end{array}$ & $\begin{array}{l}\text { Feelings of } \\
\text { fulfilment, } \\
\text { pride, and } \\
\text { self-esteem }\end{array}$ \\
\hline $\begin{array}{l}\text { Experience of } \\
\text { meaninglessness }\end{array}$ & Disorientation & $\begin{array}{l}\text { Demotivation, } \\
\text { boredom, } \\
\text { depression }\end{array}$ & $\begin{array}{l}\text { Angst, } \\
\text { feelings of } \\
\text { failure }\end{array}$ \\
\hline
\end{tabular}

\footnotetext{
${ }^{11}$ For existential feelings, see Matthew Ratcliffe, Experiences of Depression: A Study in Phenomenology (Oxford: Oxford University Press, 2014).
} 
Next, if our lives are meaningful to the extent that it is fitting for us to experience them as meaningful, distinguishing between these three kinds of experience suggests there are the following three forms of meaning in life, or three ways in which experiences of meaning may be warranted or correct in the light of opinion-independent facts about value and reasons: Meaning: S's life is meaningful to the extent that the actions and events that comprise it fit into a culturally recognizable narrative of pursuing some sufficient good. ${ }^{12}$ (For example, you might be a knight errant seeking the Holy Grail, or a former addict trying to make amends.)

Meaning: S's life is meaningfulp to the extent that she pursues high-level ends she has subjective and objective reason to pursue. (For example, you might organize your activities around the aim of preventing coral bleaching, or just taking care of aging parents.)

Meaning ${ }_{M}$ S's life is meaningful $l_{M}$ to the extent that her actions over time merit fulfilment and pride, which entails (at least) non-accidentally successful pursuit of challenging aims that she identifies with and has objective reason to pursue. ${ }^{13}$ (For example, by the sweat of your brow, you might succeed in finding a way to prevent coral bleaching.)

We might say that what ties all of these notions together is that they have to do with having a reason to go on living or there being a point to one's life. These are presumably the kind of

\footnotetext{
${ }^{12}$ As Michael Hauskeller highlighted for me, this definition implicitly relativizes meaning-as-intelligibility to culture. I think this is the right result - some lives that made perfect sense in the $13^{\text {th }}$ century wouldn't make sense now. But those who think that intelligibility should not be relative can remove the word 'culturally' from the thesis.

${ }^{13}$ As Thaddeus Metz pointed out to me (personal communication), meaningfulness-as-mattering is compatible with a degree of outcome luck - indeed, often projects that yield exceptional meaning when successful are particularly risky, like organizing a union in a repressive political environment. Not everything that requires luck is accidental.
} 
things people wonder about when they ask if their lives have meaning. We might also say that a life is superlatively meaningful to the extent that it is meaningful in all these ways.

For our purposes, it is important to say how events can be meaningful in the sense of contributing to meaning in life. In ordinary talk, to be sure, we talk about meaningful events more broadly, so that an event that has any kind of emotional resonance, or makes a significant difference to what happens later, can be said to be meaningful. But here we are interested in how an event like death can contribute to meaning in life. Given the earlier distinctions, my proposal is the following:

An event contributes to meaning to the extent that it promotes or constitutes one's life fitting into a culturally recognizable narrative of pursuing some good. (For example, getting fired after a transgression contributes to intelligibility - a lot of events fit into culturally recognizable narratives of pursuing some good. Getting fired without a discernible cause, in contrast, can be disorienting and puzzling.)

An event contributes to meaning ${ }_{P}$ to the extent that it promotes or constitutes having a high-level aim that there is sufficient subjective and objective reason to have. (For example, a moral insight or religious conversion might contribute to purpose in life.)

An event contributes to meaning $g_{M}$ to the extent that it promotes or constitutes the successful realization of a challenging identity-defining aim that there is sufficient objective reason to pursue. (For example, doing research that turns out to result in a new scientific discovery might contribute to mattering.) 


\section{Varieties of Dying for a Cause}

With these distinctions in hand, let us turn to dying for a cause. Let's start with the question of what a 'cause' in the relevant sense is. I will say that when you take up a cause you commit to trying to right a wrong. In paradigm cases, there is some group of people who are at least perceived to be treated seriously unjustly by some other group of people who benefit from the status quo, so that there is a strong (apparent) reason for anyone in a position to change this intrinsically bad state of affairs to do so. The injustice could be denial of rights, denial of national self-determination, or discrimination on a morally irrelevant basis. That is why there is the cause of civil rights and Palestinian and women's causes. Of course, not all causes involve injustice to people - there are also environmental causes, and more broadly pursuit of some important impersonal value that some people fail to respond to. Note that it follows that when you have a cause, you have an antagonist, some group of people who benefit or at least think they benefit from the way things are, and that antagonist is likely to be powerful, since otherwise things wouldn't be such as to favour their perceived interests over those of others. And that means you have to fight for a cause, which will involve risk and thus require courage. It is no wonder that successfully acting in the service of a good cause is a prime candidate for leading a superlatively meaningful life - after all, people like Mandela and Gandhi are paradigm examples of meaning.

\subsection{Death and Intentionality}

Turning to dying for a cause, then, the first basic distinction I shall make is between different aims in relation to death. For the most part, when we think of someone dying for a cause, we think of people who risk their lives in the service of some cause they are committed to. This 
includes people like Hans Scholl, or the Parisians who set up barricades in 1870, or human rights activists in many former parts of the Soviet Union. Such people do not in any sense aim to die for their cause - indeed, they typically try their best to avoid death, as long as that is compatible with working for their cause. But their commitment to it is so strong that they would rather act and die than fail to act and live. Hans Scholl knew that he could easily be caught for writing and distributing leaflets critical of the Nazi regime, and that he would be executed if he were, but it was more important for him to follow his conscience than to live in the relative safety of silence. While such people do not choose to die, they do choose to act in the face of significant risk of death rather than betray their values, and can thus appropriately be said to have died for their cause if they are killed in its service.

However, there are also people who do choose to die for a cause, and not merely risk their lives for it. Perhaps the purest example of aiming to die for a cause are people who publicly kill themselves to redirect the attention of the public to their cause. Think here of the Buddhist monk Thích Quảng Đức who burned himself to death during the Vietnam War to call attention to religious inequality in the country, or the Tunisian street seller Mohamed Bouazizi, who likewise set himself on fire to protest arbitrary and humiliating treatment by authorities, sparking the Tunisian revolution of 2011. ${ }^{14}$ Psychologists interested in selfsacrifice often focus on suicide bombers as an example of this category, and it does seem that some of them specifically seek martyrdom (see Section 4). However, I suspect that many suicide bombers simply use themselves as guidance devices for explosives and would save themselves if they could - their aim is to kill other people, and their own death is a side effect rather than a means to their aims.

\footnotetext{
${ }^{14}$ For information about Đức and Bouazizi, I'm relying on their Wikipedia entries, respectively https://en.wikipedia.org/wiki/Th\%C3\%ADch Qu\%E1\%BA\%A3ng \%C4\%90\%E1\%BB\%A9c and https://en.wikipedia.org/wiki/Mohamed Bouazizi.
} 
Not all who can be said to choose to die unambiguously aim at death, however. Consider hunger strikers like the Irish Republicans Terence MacSwiney in 1920 and Bobby Sands in 1981. Roughly speaking, they demanded recognition as political prisoners rather than mere criminals. They didn't aim to die as such, but neither did they just accept a risk of dying - after all, they knew they would die if they continued to reject nutrition. ${ }^{15} \mathrm{We}$ might say they placed their lives in the hands of their antagonist, forcing the British government to choose between outrage at their deaths or yielding to their demands. Still, at the point at which it became clear to them the British would not in fact yield, they did choose to do something - refuse nutrition - which they knew would result in their death in the belief that by doing so they would serve their cause. ${ }^{16}$ Indeed, Sophie Scholl stands out among the members of the White Rose in making a similar choice in virtue of declining to recant, and thus choosing to be killed rather than only risking being killed. (Of course, unlike the hunger strikers, she didn't kill herself.)

\subsection{Death, Success, and Failure}

Besides kinds of intentionality, we can also make an orthogonal distinction between death successfully serving a cause and failing to do so. Sometimes a person's death does have an instrumental role in furthering a cause. The very fact that Bouazizi died in his selfimmolation in all likelihood played a role in the impact his act had. Similarly, Đức's act really did shock the conscience of the world and led to the US forcing the Vietnamese to

\footnotetext{
${ }^{15}$ Since both MacSwiney and his comrades were Catholic (and fighting for the cause of predominantly Catholic Irish people), the Catholic Church was forced to take a position on their hunger strikes. This resulted in interesting theological debates about whether starving oneself to death in such circumstances was suicide (and thus prohibited) or not (see Scull 2016). For example, Father P.J. Gannon pointed out in 1920 that in a hunger striker 'There is nothing of the mentality of a suicide, whose object is to escape from a life that has grown hateful to him.' (quoted in Scull 2016, 293)

${ }^{16}$ As MacSwiney wrote during his strike, 'If I die I know the fruit will exceed the cost a thousand fold. The thought makes me happy.'
} 
improve the treatment of Buddhists. MacSwiney's death from hunger strike increased sympathy for the Republican cause and inspired future revolutionaries from Gandhi to Ho Chi Minh. ${ }^{17}$ Even the Scholl siblings had at least some reason to believe that if they were to be caught and martyred, it would further the cause of resistance to the Nazis at least by breaking the illusion of uniform support for the regime, though in fact the immediate effects were minor. ${ }^{18}$ In all of these cases, the mechanism of promoting the cause is something like the death redirecting the attention and motivation of other people in a way favourable to the cause. If third parties are at all charitable, news of such deaths easily leads them to wonder what is so wrong with the way that Buddhists or the Irish are being treated as to make some of them willing to give up their lives to change it, or make the relevant injustice salient. Such thoughts and inquiries can lead to anger and then action. And the very courage and willingness to sacrifice displayed by people who take the risky first steps against some powerful antagonist (recall Sophia Scholl's insistence that 'someone had to make a start') can itself inspire others to act on their convictions.

Of course, dying for a cause doesn't always serve the cause in any way. It is not a coincidence that it is not as easy to think of concrete examples of this - going unnoticed or being soon forgotten is constitutive of failing to make a difference by dying. But take Joseph Murphy, who was captured along with MacSwiney and also went on hunger strike in Cork Gaol, dying on the same day as MacSwiney. ${ }^{19}$ As it happened, his sacrifice went nearly unnoticed in the shadow of the more famous man's death and can hardly be said to have

\footnotetext{
${ }^{17}$ See Jason Perlman, 'Terence MacSwiney: The Triumph and Tragedy of the Hunger Strike', New York History 88 (2008). Online at https://web.archive.org/web/20081204101849/http://www.historycooperative.org/journals/nyh/88.3/perlman.ht $\underline{\mathrm{ml}}$.

${ }^{18}$ Hanser describes the group's aims as follows: "For them, an immediate, visible result was not an important consideration. What was important was to launch a moral protest, to send out a cry of conscience. They wanted to make a start at eroding the faith of the German people in their leadership, to let their fellow dissidents know that they were not alone and that the monolith of public support for the regime was a propaganda myth." (Noble Treason, 167)

${ }^{19}$ Perlman, 'MacSwiney'.
} 
made any difference. Or, for a case of aiming to die, consider the death of Irina Slavina. Who? She was a Russian journalist who burned herself to death in 2020 in protest at the constant harassment of independent journalists by the authorities. ${ }^{20}$ Very sadly, her death doesn't seem to have made a difference, and I would wager that few of us have heard of it. When it comes to cases in which people accept the risk of death for a cause, they don't usually even think death would promote the cause, but simply accept it as a potential price to pay without allowing themselves to be deterred by it. For example, Rosa Luxemburg's death at the hands of the Freikorps in January 1919 didn't help along a communist revolution in Germany. We can summarize these distinctions and examples in the following table:

\begin{tabular}{|l|l|l|}
\hline & Death serves the cause & $\begin{array}{l}\text { Death doesn't serve the } \\
\text { cause }\end{array}$ \\
\hline $\begin{array}{l}\text { Death is accepted for } \\
\text { the cause }\end{array}$ & Hans Scholl & Rosa Luxemburg \\
\hline $\begin{array}{l}\text { Death is chosen for the } \\
\text { cause }\end{array}$ & $\begin{array}{l}\text { Sophie Scholl, Terence } \\
\text { MacSwiney }\end{array}$ & Joseph Murphy \\
\hline $\begin{array}{l}\text { Death is sought for the } \\
\text { cause }\end{array}$ & $\begin{array}{l}\text { Thích Quảng Đức, } \\
\text { Mohamed Bouazizi (?) }\end{array}$ & Irina Slavina \\
\hline
\end{tabular}

\section{Living Meaningfully and Dying for a Cause}

With this understanding of the varieties of dying for a cause, let us turn to the issue of how death for a good cause might contribute to different kinds of meaning (I will discuss bad causes later). Given what I said earlier about contributing to meaning as mattering, we get the following principle:

${ }^{20}$ The New York Times, October 2, 2020. 
Death contributes to meaning $\mathrm{M}_{\mathrm{M}}$ to the extent that it non-accidentally promotes or constitutes the successful realization of a challenging and identity-defining aim that there is objective reason to pursue.

Clearly, we must look here to cases in which death does end up serving the cause in some way. Start with aiming at death. As far as I know, Đức was deeply committed to the presumably good cause of religious equality in Vietnam, and resorted to self-immolation only when nothing else worked. Promoting the aim in this way was certainly challenging, and took a lot of courage. And as I noted above, his death really did make a difference as a result of the bad publicity for the government, and was meant to do so. So it can be said to have contributed significantly to his life being meaningful in the sense of mattering. It seems to me that very much the same goes for cases of choosing to die without aiming at death, like those of Sophie Scholl and Terence MacSwiney.

Where death is merely accepted, however, and thus only comes about as a side effect of other efforts, it becomes in a relevant sense less expressive of who one is. It is not itself either a part of the plan or a foreseen consequence of one's choice. That is why I would suggest that Hans Scholl's death contributed somewhat less to meaning $g_{\mathrm{M}}$ than his sister's, since he didn't get to make the choice about whether or not to die after being caught.

However, here it is good to remember that often the actions of people who fight for a good cause at the risk of losing their lives make a greater positive difference than their deaths - if you die in the course of blowing up the last bridge across the river to allow refugees to escape, it is blowing up the bridge that makes your life matter, not your dying. Similarly, even if Hans Scholl's death as an event in itself contributed less to meaning than his sister's, he was the founder and leader of the White Rose and the main author of most of their 
pamphlets, and those valuable activities chosen in spite of high risk of dying certainly were expressive of his identity and gave considerable meaning to his life.

What about meaning as purpose, then? The earlier discussion suggests the following criterion:

Death contributes to meaning to the extent that it is a high-level aim that there is subjective and objective reason to pursue.

Again, we see that dying for a cause does contribute to purpose in life for people who aim to die for a cause and whose death serves it. But an important difference here is that dying for the cause of free journalism can contribute to the meaningfulnessp of Irina Slavina's life, for example, even if it doesn't end up serving the cause. Consequently, it can make motivation and striving for it fitting. Some might protest here that someone like Slavina could also take pride in her actions and is a rightful target of admiration, in spite of her death's instrumental inefficiency, which suggests that her death also contributes to meaning as mattering. I think there's some truth to this, but what it ultimately points to is just that we can see it as part of the aim of someone like Slavina to show that there are still some people in Russia who have the moral integrity to choose death rather than submission to autocracy. Her action certainly realized that valuable aim and was to that extent successful even if it didn't shake the autocracy itself.

What about people who choose death without strictly aiming at it - does dying for a cause contribute to purpose in their lives? I think it follows from what I have said that it doesn't. But I am not yet sure, because I am not quite sure what to say about the intentionality of their dying for the cause, since it doesn't seem like a mere foreseen side effect of, say, refusing nutrition. In contrast, death itself clearly doesn't provide purpose for those who 
merely accept a significant risk of it for a cause. Other things being equal, their actions would be just as meaningful were they miraculously saved. Imagine that rebel elements within the German armed forces had rescued Hans Scholl at the last minute, and he would have survived the rest of the war in Switzerland. That wouldn't have in any way undermined the purposefulness of his White Rose activities.

Finally, what about intelligibility and dying for a good cause? The principle looks something like the following:

Death contributes to meaning to the extent that it promotes or constitutes making the actions and events that comprise one's life fit into a culturally recognizable narrative of pursuing some good (a hero narrative).

Here, I think it is good news all around for dying for a good cause. There definitely is a hero narrative shared among a wide range of cultures, in which people sacrifice themselves for the sake of the common good. For such a death to add to the arc of one's life making sense, it need not be in any way successful - dying in vain for a good cause is a common variant of tragedy. Nor does it matter from the point of view of intelligibility if the death is an unwelcome side effect of fighting a more powerful enemy. It will still provide a recognizable closure that may be missing if one merely wastes away from illness.

The downside is that intelligibility is a low bar. Other things being equal, a life that makes sense may be better for a person than a life that doesn't. For example, Helena de Bres argues that intelligibility allows for the goods of mutual understanding and community. ${ }^{21} \mathrm{But}$ these alone are not the kind of values for the sake of which it is a good idea to give up an otherwise good life - especially since it also makes sense to give up your cause instead to save your life.

${ }^{21}$ De Bres, 'Narrative'. 
One question you might have at this point is that while it may be plausible enough that events during your life contribute to its meaningfulness in something like the way I have suggested, just when could death possibly make your life more meaningful? Seemingly, it can't do so once you die, and before that it hasn't even happened. I don't think this puzzle can be solved without endorsing retrospective value change. Luckily, then, I have defended such a view in various places. ${ }^{22}$ Roughly speaking, I believe that death can change the teleological significance of prior actions that lead to it, and consequently make them more (or less) meaningful. ${ }^{23}$

\section{Meaning, Self-Interest, and Self-Sacrifice}

In his book on the White Rose resistance movement, Richard Hanser says that for the members of the movement 'there was something worse than arrest, trial, and execution. What was worse was living without protest under a system that, by its nature, was the enemy of all decencies on which civilized intercourse among human beings rested ${ }^{24}$. This is a very natural thing to say about the cases we are interested in. But if it had been worse for Sophie Scholl to live under the Nazis than to die, we are faced with a kind of puzzle. After all, it seems that one of the reasons we admire people like her and are grateful to them if we are among the beneficiaries of their act is that they sacrificed themselves for a good cause. Some may even think that it is precisely sacrificing their lives for a cause that made them meaningful (although I think this is a mistake - roughly, it's doing objectively good things in the face of challenges that gives meaning to their lives). But if dying for protesting was better for the

\footnotetext{
${ }^{22}$ Such as Antti Kauppinen, 'The Narrative Calculus', Oxford Studies in Normative Ethics 5 (2015), 196-220 and Antti Kauppinen, 'Prudence, Sunk Costs, and the Temporally Extended Self', Journal of Moral Philosophy 17 (2020), 658-681.

${ }^{23}$ Kauppinen, 'Prudence', 668.

${ }^{24}$ Hanser, Noble Treason, 20.
} 
Scholls - most likely in virtue of making their lives more meaningful than otherwise - than living much longer without protest, it seems they didn't after all sacrifice themselves, since they chose what was best for themselves. On the face of it, this is so implausible that it calls into question the thesis that dying for a good cause can make one's life meaningful.

To examine this challenge, let us start by defining self-sacrifice more precisely. As it is standardly understood, self-sacrifice involves knowingly and voluntarily choosing an option that is all-things-considered bad for yourself, and worse than other available alternatives, because you regard something else as more important than your self-interest. ${ }^{25}$ Why are all these things required? Clearly, if you are forced to do something that is good for others and bad for you, you are not sacrificing yourself (though you may be sacrificed), so it must be a free choice. Similarly, if you choose to do something that is in fact all-thingsconsidered bad for you and good for a cause because of falsely believing that you are serving your interests, you are not self-sacrificing, and merit little gratitude, so you must believe that it is all-things-considered bad for you. Call this the subjective condition of self-sacrifice. (It is evidently no self-sacrifice either if you do something you think is in some way bad for you, but in other ways good for you, and the good outweighs the bad - it is no self-sacrifice to go to a dentist.) On the other hand, if you falsely believe that serving some good cause is bad for you when it in fact benefits you, that is not self-sacrifice either, though in this case you may merit some admiration. So you must correctly believe, and better yet know, that serving the cause is all-things considered worse for you. Call this the objective condition of self-sacrifice. It must plausibly also be something positively bad and not just a less good option - at least, it is not much of a self-sacrifice to holiday on Corfu rather than Santorini because it happens to provide some benefit to refugee children.

${ }^{25}$ See Mark Overvold, 'Self-Interest and the Concept of Self-Sacrifice', Canadian Journal of Philosophy 10 (1980), 105-118 and Chris Heathwood, 'Preferentism and Self-Sacrifice', Pacific Philosophical Quarterly 92 (2011), 18-38. 
It follows that there are two basic ways in which dying for a cause can fail to amount to self-sacrifice, setting aside the issue of positive badness:

Failure of subjective condition. If S believes she can either a) die for her cause or b) give up her cause and live, and believes that a is all-things-considered better for her than b, and chooses a because she believes so, she doesn't sacrifice herself by choosing a.

Failure of objective condition. If S can either a) die for her cause or b) give up her cause and live, and a is all-things-considered better for her than b, she doesn't sacrifice herself by choosing a.

\subsection{The Subjective Condition of Self-Sacrifice}

Let us start our examination of when dying for a cause amounts to self-sacrifice with the subjective condition. It is certainly possible for someone to reason in the following fashion: 'Dying for the cause will make my life significantly more meaningful than giving it up to live. Meaning is a really important good in a life. So, it is in my overall self-interest to lead a significantly more rather than less meaningful life, even if it means losing many years of happiness and other goods. So, I will fight for my cause at the risk or price of death.' A person who thinks this way will fail the subjective condition of self-sacrifice. Their reasoning is relevantly similar to someone who thinks it is in her overall self-interest to go to a dentist, even though it means enduring some unpleasantness for a while. But for our purposes, the key question is whether someone who dies for a good cause must think in this way. And of course, for each particular individual, such as Sophie Scholl, we can ask whether they did think in this way. 
The question of whether people who die for a cause in fact meet the subjective condition is an empirical one. Psychologists have studied people's motives for (apparent) self-sacrifice or martyrdom ${ }^{26}$ especially in the context of suicide terrorism in places like Palestine, Sri Lanka, and Chechnya. Interestingly for our purposes, the leading hypothesis, defended by, among others, Arie Kruglanski and his colleagues, does seem to be that suicide bombers are typically motivated by 'quest for significance'27, or 'the desire to count, to be someone, to be recognized, to matter in the eyes of one's group, according to its (sacred) values $^{28}$ - roughly, a desire for meaning-as-mattering and living on in the collective memory of one's group - that is postulated to be a basic human motive, even a need. As Kruglanski and colleagues put it,

On this analysis, the underlying motivation for suicide terrorism involves the coupling of a quest for significance with a collective crisis situation, involving a perceived threat to one's group, and a terrorism-justifying ideology whereby a suicide attack is portrayed as an act of heroic sacrifice (martyrdom) lending one's existence and demise an aura of supreme glory. ${ }^{29}$

This claim is supported by various sorts of empirical studies. Many are conducted in the tradition of Terror Management Theory, according to which, very roughly, fear of death and insignificance motivates people to attach themselves to groups and embrace cultural worldviews or 'ideologies' that promise them at least symbolic immortality, a role in

\footnotetext{
${ }^{26}$ Jocelyn Bélanger, Julie Caouette, Keren Sharvit, and Michelle Dugas, 'The Psychology of Martyrdom: Making the Ultimate Sacrifice in the Name of a Cause', Journal of Personality and Social Psychology 107 (2014), 494-515.

${ }^{27}$ Arie Kruglanski, Xiaoyan Chen, Mark Dechesne, Shira Fishman, and Edward Orehek, 'Fully Committed: Suicide Bombers' Motivation and the Quest for Personal Significance', Political Psychology 30 (2009), 331357.

${ }^{28}$ David Webber, Kristen Klein, Arie Kruglanski, Ambra Brizi, and Ariel Merari, 'Divergent Paths to Martyrdom and Significance Among Suicide Attackers', Terrorism and Political Violence 29 (2017), 852-874, at 853.

${ }^{29}$ Kruglanski et al., 'Quest for Personal Significance', 337.
} 
something greater than themselves ${ }^{30}$ Consequently, being reminded of mortality (for example, when one's family members are killed by an occupying power ${ }^{31}$ ) or being made to feel insignificant increases people's motivation to support their group and make a mark on the world in ways endorsed by the prevailing ideology, including by participating in suicide missions when there is a grievance that calls for violent retaliation. And indeed, unsurprisingly, many would-be suicide terrorists justify their actions by appeal to defending their religion or nation. ${ }^{32}$ Conversely, people who strongly identify with their religion or nation are more supportive of terrorism than others and are less anxious about their own death. ${ }^{33}$

Of course, it doesn't follow that people willing to die for a cause are at bottom on a quest for personal significance - they could care about defending the honour or safety of their ethnic group for its own sake and not only instrumentally. So the important question is whether people would choose or risk death for a cause if there was a possibility to gain (or restore, or avoid the loss of) significance in some other way, or if they didn't see it as a means to personal significance in the first place. The best evidence I have been able to find for significance motivation comes from two sources: first, some suicide terrorists seem to have turned to it after personal failure (doing something shameful, losing a job) ${ }^{34}$, and second, some deradicalization programs, such as the one targeting incarcerated Tamil Tigers

\footnotetext{
${ }^{30}$ See e.g. Sheldon Solomon, Jeff Greenberg, and Tom Pyszczynski, The Worm at the Core: On the Role of Death in Life (New York: Random House, 2015).

${ }^{31}$ Anne Spekhard and Khapta Akhmatova, 'The Making of a Martyr: Chechen Suicide Terrorism', Studies in Conflict and Terrorism 29 (2006), 1-65, found that all Checzhen suicide attackers in the 2002 Moscow theatre siege had had family members killed or tortured by Russians or their cronies, which Kruglanski and colleagues interpret as supporting the death reminder theory ('Quest for Significance', 339). One wonders, though, if arousing righteous anger or desire for vengeance isn't a simpler explanation - family deaths by natural causes should also remind one of mortality, but would they motivate suicide terrorism? Similarly, Webber et al. ('Divergent Paths') code terrorists who have lost a loved one to violence as being motivated by loss of one's own personal significance, which again ignores the simpler emotional explanation.

${ }^{32}$ Kruglanski et al., 'Quest for Personal Significance', 340-344.

${ }^{33}$ Edward Orehek, Jo Sasota, Arie Kruglanski, Mark Dechesne, and Leianna Ridgeway, 'Interdependent SelfConstruals Mitigate the Fear of Death and Augment the Willingness to Become a Martyr', Journal of Personality and Social Psychology 107 (2014), 265-275.

${ }^{34}$ Webber et al., 'Divergent Paths', 860.
} 
in Srik Lanka, appear to succeed in virtue of offering people alternative routes to significance by way of vocational education. ${ }^{35}$ While this evidence is inconclusive, it suggests that in some cases risking one's life for a cause is motivated by a deeper desire to gain or restore a sense of mattering.

So, there is some psychological evidence that some people who die for a cause fail to meet the subjective condition for self-sacrifice, since if you do something ultimately because you think it will make your life more significant and therefore better in one way, you are not knowingly choosing the option that is worse for you. But evidently the empirical results come nowhere near showing that this must be the case. It is perfectly possible and is supported by what we know about the Scholl siblings that somebody reasons along the following lines: 'Getting ordinary Germans to rise up against tyranny is supremely important. This moral evil must be stopped, even if it means losing many years of happiness and other goods for me. So I will pursue rebellion against the regime even at the risk or price of death.' Someone who reasons in this way chooses an option they think is morally better in the belief that it is or may easily be prudentially worse. She doesn't aim at making her own life meaningful, but at making the world less bad. She need not at all think about the meaning of her own life or her self-interest, or how others will think of her afterwards. But whether she as a matter of fact does so - and clearly, there is evidence in the quotations I started with that Sophie Scholl, for example, wasn't insensitive to meaning ${ }^{36}$ - the crucial thing is that she doesn't make her

\footnotetext{
${ }^{35}$ Arie Kruglanski, J Jocelyn J. Bélanger, Michele Gelfand, Rohan Gunaratna, Malkanthi Hettiarachchi, Fernando Reinares, Edward Orehek, Jo Sasota, and Keren Sharvit, 'Terrorism: A Love Story: Redirecting the Significance Quest Can End Violence', American Psychologist 68 (2013), 559-575, at 572-573.

36 There is even more to suggest that Hans Scholl was motivated to some extent to make his life matter. According to the biographer Richard Hanser, his favourite book as a boy was 'a collection of article-essays by Stefan Zweig called Sternstunden der Menschheit, a title that loses something in English - "Stellar Hours of Mankind". In it Zweig described a variety of crucial moments from which some enduring significance for coming generations flowed' (Noble Treason, 53). It is unsurprising, then, that Hans 'felt that he himself was being summoned to act heroically' and had 'a deep strain of idealism that demanded that life have a meaning, that activity have a basis in purpose' (Noble Treason, 38). Perhaps it could be said that the felt need for mattering initially got Hans to look for some way to make a valuable contribution, but most likely once he had committed to the cause of undermining the regime, any self-directed motives faded into the background.
} 
choices because she thinks it is best or most meaningful for her. She at least would act the same way even if she didn't think so.

To put it differently, what people seek whose choices meet the subjective condition of self-sacrifice are things that make their lives meaningful de re, not things that make it more meaningful de dicto. That is to say, it is true of the aims that they pursue, such as resisting the dictatorship, that pursuing them makes their lives meaningful (that is the de re reading), even though they don't pursue them under the description of making their lives meaningful (as the de dicto reading would have it). It is only if they pursued what makes their life meaningful de dicto that they would be motivated to engage in self-focused reasoning about which option would best promote meaning, and be prepared to change their project if another, less costly option were to emerge. It is worth noting that such reasoning is at least to some extent selfdefeating, since if you, say, try to bring down a tyrannical regime just in order to make your life more meaningful and just as long as you think it will do so, you are not genuinely committed to bringing down the regime (since commitment would entail that you wouldn't trade it for another option just because it looked better from the perspective of your personal meaning). And if your actions don't express your commitment, they are not as deeply rooted in who you are as they could be, and therefore contribute less to making your life meaningful even if they are successful.

\subsection{The Objective Condition of Self-Sacrifice}

I have argued that we don't have reason to think that people who die for a cause always or generally fail the subjective condition of self-sacrifice. But what about failing the objective condition? With some plausible additional assumptions, this is a real challenge to my view. I have argued that dying for a cause can indeed make a person's life more meaningful. If that is 
combined with the assumption that meaning in life is a very important prudential good - that it is very much in our self-interest to lead a more rather than less meaningful life - it follows that it can relatively easily turn out that it is better for someone to die for a cause rather than to live a longer, less meaningful life. And if that is so, then my view entails that even a person who subjectively sets her self-interest aside may end up doing what is best for her, and thus won't sacrifice herself, because she fails the objective condition. This is a challenge to my view, since people who die for a cause often do sacrifice themselves for it. So I must explain why acts that give great meaning to our lives can nevertheless be all-things-considered bad for us.

An easy way out would be to deny that meaning in any of three varieties I have mentioned is in our self-interest. And there certainly are theories of well-being, such as forms of hedonism and subjectivism, according to which it is only instrumentally or contingently good for us, respectively, either by way of contributing to pleasure or happiness or by being something we desire or value. If that were the case, it would be easy to show that in most cases of dying for a cause the person would get more pleasure or satisfy desires better by saving themselves. And even if some more objectivist theory of well-being is true, it could be that meaning in life is a value that is distinct from well-being or self-interest. Some of the things Susan Wolf says are in this vein, especially when she highlights the contrast between reasons of self-interest and reasons of love, when the latter are involved in many meaninggenerating activities according to her. ${ }^{37}$ But if we look at her work more carefully, the real contrast she tends to draw is between meaning and happiness. ${ }^{38}$ And plausibly, there is more to self-interest than happiness.

\footnotetext{
${ }^{37}$ Susan Wolf, Meaning in Life and Why It Matters (Princeton, NJ: Princeton University Press), at 51.

${ }^{38}$ E.g. Wolf, Meaning in Life, 49.
} 
Most famously, the idea that happiness is not all that matters for well-being is supported by the often misunderstood Experience Machine thought experiment. ${ }^{39}$ As Eden Lin notes, properly construed it involves two subjects who lead experientially identical lives and thus are equally happy, but while one of them derives her happiness from actual achievements and interactions, the other's experiences are surreptitiously generated by a supercomputer she is plugged into while passively lying in a tank. ${ }^{40}$ If happiness were the only thing that matters, the lives of these two people would necessarily be equally good for them. But they are not - other things being equal, it is better for you to feel the same amount of joy for actually winning a prize than for having the perfect illusion of doing so - so there must be more to self-interest than happiness. But what else? I can't argue for it here, but I believe that meaningfulness (as mattering or purpose or both) is a good candidate for a feature that unifies such things as valuable achievements and successful personal relationships. Indeed, as many from Nozick onwards have suggested, the most appealing explanation of why a perfectly happy life in an Experience Machine is not the best possible one is that it is notably lacking in. All the standard tests for what kind of life is prudentially good also point to meaning being among welfare goods - other things being equal, we wish for our children to grow up to lead meaningful rather than meaningless lives, and not just because we think that would be instrumentally beneficial to them; other things being equal, we envy people who lead more rather than less meaningful lives, and so on. And it is not just hedonism but also subjectivism that struggles to explain this, since for a subjectivist meaning is only good for us if we desire or value it. ${ }^{41}$ Yet it seems all the more tragic if a child grows up not valuing the things that would de re make her life meaningful.

\footnotetext{
${ }^{39}$ Robert Nozick, Anarchy, State, and Utopia (New York: Basic Books, 1974).

${ }^{40}$ Eden Lin, 'How to Use the Experience Machine', Utilitas 28 (2016), 314-332.

${ }^{41}$ For sophisticated subjectivism, see Valerie Tiberius, Well-Being as Value Fulfillment: How We Can Help Each Other to Live Well (New York: Oxford University Press, 2018).
} 
So, there is at least a good prima facie case for thinking that meaning is a welfare good, something in itself and non-instrumentally good for us. But that means we must take head-on the challenge of showing how a significantly more meaningful life resulting from dying for a good cause and thereby (or as a result of) successfully promoting it can be allthings-considered worse for you than saving oneself. Given that on any plausible theory of well-being, meaningfulness is not the only welfare good, there are two possibilities: either the losses in terms of other goods outweigh the gains in meaning, or there is a net loss of meaningfulness. Fortunately for meeting the objective condition of self-sacrifice, we find both of these in our paradigm cases.

Let us start with the more straightforward case, the greater loss of other goods. It is probably not a coincidence that when we think about cases of self-sacrifice, we tend to focus on the young who would otherwise have a lot of good life ahead of them. While it is difficult if not impossible to give anything like precise weights to different components of any pluralist conception of well-being, it seems clear that sixty years of a happy life that is neither meaningless nor particularly meaningful is better for you than a very meaningful life that lasts only twenty years. The Scholl siblings, for example, might well have survived the war and gone on to live ordinary happy lives filled with friendship, achievement, and culture, despite quite possibly occasionally feeling ashamed for having been quiet during the Hitler regime. On the other hand, if a very old person goes out in a blaze of glory, her act may be admirable for its inherent or instrumental value and the courage it takes to face pain, but may well not amount to genuine self-sacrifice, if the alternative is joylessly withering away.

But wait - what if Sophie Scholl had, unbeknownst to all, a congenital heart condition that would have caused her to die in March 1943 anyway? My account would then entail that it is, after all, in Sophie's best interest to die for her cause, so that it doesn't amount to selfsacrifice. But that, to me, is the right thing to say. An informed advisor concerned only for 
Sophie's good would have good reason to tell her to choose the more meaningful option rather than the marginally longer life that would be considerably less meaningful, even if it contained somewhat more happiness. If you are not convinced, suppose that Sophie knew that she was going to die soon anyway. Her choice of sticking with her group would look a lot less like a self-sacrifice in that case.

A different kind of protest might start from the idea that even if Sophie would have died a week later anyway, as long as she didn't know that, her choice is admirable in virtue of being an instance of self-sacrifice. My response is to grant that her choice would indeed be admirable, but not because it would be a case of self-sacrifice, but because of her willingness to sacrifice herself for a good cause. It would be analogous in this respect to jumping in front of a raging bull in order to rescue some unknown children only for the bull to fall into a trap just before it gets to you. In such a situation, you wouldn't have in the end sacrificed yourself to save the children - indeed, if a grateful billionaire mother granted your every wish as a result, your action might well turn out to have been very much in your best interests. Still, the gratitude wouldn't be misplaced, since your action would nevertheless have manifested a virtuous willingness to sacrifice yourself for the sake of a great value.

I take it that it should be fairly obvious that the more meaningful choice can result in overall worse consequences for a person even if meaning counts towards self-interest. But it can also be the case that the more meaningful choice results in overall loss in terms of meaning itself. Consider the following possible lives for someone like Sophie Scholl:

Life A: Sophie gets caught for distributing anti-Nazi leaflets; Sophie refuses to renounce her opposition; Sophie gets sentenced to death and executed on February 23, 1943.

Life B: Sophie gets caught for distributing anti-Nazi leaflets; under pressure, Sophie recants and is sentenced to community service; immediately after the war, Sophie 
begins collecting evidence of Nazi atrocities, and for the next five decades, keeps the memory of the horrors alive for new generations, before succumbing to cancer on June 7, 1997.

For reasons discussed earlier, life A is more meaningful than life B until February 23, 1943 (and indeed for a considerable time after). But as Sophie in life B begins her important work in making sure that later generations never forget, her life gradually gains in meaning, and may eventually overtake life A in that respect. What this shows is that even choices that significantly contribute to meaning in life need not make the life more meaningful than it would otherwise have been. ${ }^{42}$ They can thus amount to sacrifice in terms of meaning itself, and not just in terms of other prudential goods.

\section{Conclusion}

To sum up, I have argued that dying for a good cause can contribute to meaning in life in its various senses. If death itself is chosen and serves the cause, it plays a part in making one's life leading up to it matter. If death is a worthwhile aim in service of the cause, it can give purpose to earlier efforts, even if it doesn't have good consequences. And dying for a good cause can make for a good ending to a heroic narrative, though that is not in itself worth dying for. Insofar as having meaning in life is a good thing for an individual, there is thus something to be said for dying for a cause from the perspective of prudence. This raises the issue of how it nevertheless often amounts to self-sacrifice. The answer is that one need not

\footnotetext{
${ }^{42}$ This is structurally similar to Valerie Tiberius's observation that living up to one's values right now can result in net loss of value fulfillment in the long run, and thus amount to self-sacrifice. See Tiberius, Well-Being as Value Fulfillment, 43.
} 
choose to risk or face death because one thinks it is best or most meaningful for one, and even if such death contributes to meaning, this benefit may be outweighed by other losses, including those in terms of meaning itself.

While there thus can be something to be said for dying for a cause from the perspective of meaning, morality, and self-interest, I do want to finish by cautioning against it by pointing out three distinctive major risks. First of all, you might end up dying for a bad cause. People can, notoriously, fool themselves into thinking that their own group, religion, or race is objectively superior to others, and commit to righting perceived wrongs that are not genuine wrongs. The cause of the Southern Confederacy is a paradigm example. Such causes can, unfortunately, give one a sense of purpose and mattering. But they don't, for all that, make one's life meaningful, because the ends one pursues are not objectively worth pursuing. Second, even if the cause is genuinely good, it is almost always highly uncertain whether one's death will promote it, thus calling into question whether it will make one's life matter. And even if the action that leads to your death does promote the cause, it may be morally wrong, as happens in the rare cases of suicide terrorism that kills innocent civilians in pursuit of a genuinely good cause. Such wrongness may be a kind of undercutting defeater for a contribution to meaning. ${ }^{43}$ And finally, even if the cause is good and one's death would promote it without moral wrong, it might not be good enough to make dying for it a proportionate response. It may be important to protect neighbourhood parks against greedy property developers, but you shouldn't sacrifice your life for it. So if you wish to lead a meaningful life and are lucky enough to be able to do so without risking your life, there is much to recommend in living for a cause. ${ }^{44}$

\footnotetext{
${ }^{43}$ I owe this intriguing suggestion to Frances Kamm.

${ }^{44}$ I'd like to thank participants in the Meaning of Life and Knowledge of Death workshop for useful discussion, especially Michael Hauskeller, Daniel Hill, Frances Kamm, and Thaddeus Metz, who sent me written comments. I also owe a debt for Lilian O'Brien for her insights on several drafts of the paper.
} 